\title{
整
}

\section{Spiritualiteit in die lig van Romeine 12}

\author{
C.J.H. Venter \\ Skool vir Kerkwetenskappe \\ Potchefstroomse Universiteit vir $\mathrm{CHO}$ \\ POTCHEFSTROOM \\ E-pos: dmscjhv@puknet.puk.ac.za
}

\begin{abstract}
Splitiuality in the light of Romans 12

In this article certain central concepts in a selection of recent definitions of Reformed spirituality are investigated. These definitions are contextualized in order to direct the investigation of spirituality in Romans 12. Afier a justification for the selection of specifically Romans 12 as focus area for this article, certain elements regarding spirituality in Romans 12 are highlighted. These elements inter alia imply the founding of spirituality in the mercy and sovereignty of God, commitment to God as integral element in our spirituality and eschatological dimensions. Furthermore, the role of the church in equipping believers for a lifestyle characterized by spirituality is focused on. In conclusion certain concrete actions reflecting the fruit of spirituality according to Romans 12 are outlined.
\end{abstract}

\section{Inleiding}

'n Tema wat veral die afgelope tien jaar weer sterk in die sentrum van teologiese besinning staan, is die tema van spiritualiteit. Vanuit die pastorale wetenskap word dikwels besin oor spiritualiteit (Louw, 1997:11-25; Lartey, 1997:112-124). Ook in besinning oor die Homiletiek word deesdae sterk gefokus op die spiritualiteit van die prediker (Kim, 1997:1-7; Geluk, 1995:16-18). Artikels oor spiritualiteit in die liturgie is eweneens aan die orde van die dag (Witvliet, 1997:273-297). Beskrywing en nadere bestudering van spiritualiteit vanuit die Ou Testament (Snyman, 1997:1-13) en Nuwe Testament (Kim, 1997:73-100) kom ook aan die orde, terwyl in ons tyd opnuut besin word oor die kerk en oor die waarde van spiritualiteit in kleingroepbediening (Oostenbrink \& Lotter, 1998:118). Bloot uit hierdie oorsig is dit reeds duidelik dat ons hier met 'n aktuele en baie toepaslike tema te doen het. 
'n Verdere dimensie wat voortvloei uit hierdie oorsig, is dat teorievorming oor basisteoriee in die aangehaalde literatuur wetenskaplik wel deeglik gedoen word, maar tog 'n oorsigtelike tendens openbaar. Lartey (1997:119-124) besin veral oor die voorkoms van spiritualiteit in pastorale sorg maar werk nie sterk basisteoreties nie. Kim (1997:1-7) betrek in sy vorming van basisteoriee in die bestudering van spiritualiteit al drie die Pastorale Briewe, terwyl Snyman (1997:113) in sy besinning oor spiritualiteit tog enkele dieptesnitte maak ter wille van diepgang in sy ondersoek.

Die eiesoortige bydrae wat in hierdie artikel beoog word, is 'n verdere dieptesnit maar nou beperk tot 'n bepaalde Bybelboek (Romeine) en in dié Bybelboek weer beperk tot 'n bepaalde hoofstuk (12), juis om te probeer om meerdere diepgang te bereik in basisteoretiese navorsing in die Praktiese Teologie. Die eiesoortige bydrae wat in hierdie artikel beoog word, is basies 'n dieptesnit uit Romeine 12 rondom sekere aspekte van spiritualiteit. Die navorsingshipotese is dat Romeine 12 bepaalde gegewens oor spiritualiteit bevat wat nader ontgin behoort te word, veral met die oog op die vorming van basisteoriee vir die Praktiese Teologie.

\section{2. 'n Raamwerk vir spiritualiteit}

Om te kan kom tot 'n ontginning van toepaslike materiaal uit Romeine 12 is dit nodig om 'n nadere raamwerk te bied van wat in hierdie artikel onder spiritualiteit verstaan word. Met die oog hierop is dit nodig om sommige van die bestaande definisies nader te ondersoek en te beoordeel.

Velema (1990:74-75) omskryf spiritualiteit as “... het bezig zijn van onze geest (onder de leiding van de Heilige Geest) met pietas in de praktijk. Zo kunnen we zeggen dat pietas de kern vormt van de spiritualiteit en dat spiritualiteit uitwerking en uitwaaiering is van de pietas". Velema (1990:81-83) presiseer gereformeerde spiritualiteit dan nader deur sy definisie van spiritualiteit te belig vanuit vyf gesigspunte. Hierdie gesigspunte word omlyn as die volgende:

- Die soewereiniteit van God - God het die alleenseggenskap oor mens en wêreld.

- Vervolgens moet spiritualiteit ook besien word vanuit die feit dat ons as mense aangewese is op die openbaring van God en dat ons in geloof moet antwoord op hierdie openbaring.

- 'n Derde gesigspunt is dat ons verdorwe is en alleenlik kan lewe as God sy genade aan ons betoon in Christus. Binne hierdie derde gesigspunt kom die kerk as liggaam van Christus in die visier. Die gemeente word deur Woord en Gees byeengebring. 
- Die vierde dimensie wat Velema belig, is dat die heil in ons verwerklik word deur die Heilige Gees. Hiermee korreleer dan ons belewing van die heil in die deelkry en deelhê aan Christus se weldade in ons spiritualiteit.

- Laastens stel Velema spiritualiteit in eskatologiese perspektief. Spiritualiteit word ontvang en beleef in die bedeling van die reeds en die nog nie. Deurgaans staan die werk van God Drie-enig dan ook sentraal in spiritualiteit.

Wat opvallend is in Velema se beskrywing van spiritualiteit is die absolute plek van die Heilige Gees binne die ekonomie van die Drie-eenheid, asook die aksente op God se soewereiniteit, menslike verdorwenheid en goddelike verlossing, asook die plek van die kerk en persoonlike belewing van die heil.

Hoewel die uitdrukking coram Deo (in die teenwoordigheid van God) nie eksplisiet hier in Velema se beskrywing voorkom nie, blyk dit elders in sy werk (Velema, 1990:77) dat hy die lewe coram Deo tuisbring onder die soewereiniteit van God (vgl. ook Velema, 1992:28).

Jonker (1989:288-299) se omskrywing van gereformeerde spiritualiteit sluit nóú aan by dié van Velema en wel in die sin dat spiritualiteit die werk is van God Drie-enig, dat die Woord en Gees sentraal staan en dat ons uit genade lewe coram Deo. Dreyer (1998:5) stel ook onder andere Gees en Woord sentraal in sy beskouing van spiritualiteit.

Louw (1997:23-24) ontleed bepaalde definisies van spiritualiteit nader met die oog op die daarstelling van 'n diagnostiese model vir die assessering van spiritualiteit met die oog op geloofsgroei. Hy toon aan hoe verskillende ondersoekers elk vanuit 'n eie hoek bepaalde aspekte van spiritualiteit in hulle definisies belig. Aspekte wat hierin na vore kom, is onder andere die plek van gebed, die uitlewing van die liefdesgebod as sentrale moment in die uitlewing van spiritualiteit; die belewing van 'n persoonlike verhouding met God gepaard met 'n sinvolle verhouding met die naaste.

Nadat Louw (1997:16-17) die Nuwe-Testamentiese begrip eusebeia ontleed het, lig hy die volgende momente uit om gereformeerde spiritualiteit te beskryf: Spiritualiteit as godsvrug dui op 'n eksistensiële kennis van God met gehoorsaamheid aan God as basis. Spiritualiteit is verbind met die heilswaarheid en lei tot daaglikse geloofsinspanning en -volharding en gebed; spiritualiteit dui op 'n veranderde lewenstyl (dié van die nuwe mens - CJHV) in die daaglikse lewe. Spiritualiteit het ook ' $n$ ervaringsdimensie en spiritualiteit word coram Deo voltrek.

Van't Spijker (1998:381) toon aan dat bepaalde dimensies ook reeds sterk na vore kom in Augustinus se besinning oor spiritualiteit; die waarde van die kerk, vroomheid as vrug van God se genade en geloof in die Drie-enige God. 
Op grond van ' $n$ analise van bogenoemde outeurs se omskrywing en beredenering van gereformeerde spiritualiteit is dit duidelik dat sekere ooreenstemmende uitdrukkings telkens terugkeer. Herhalende uitdrukkings sluit die volgende in: God se soewereiniteit, sy heilsbetoning, die toe-eiening van die heil in geloof deur die werk van die Gees en die lewe in toewyding aan God en in liefde tot die naaste coram Deo in die praktyk van ons lewe van elke dag.

Die waarde van elemente wat in die verkenning hierbo na vore kom, is dat hierdeur iets van die omvang van die wetenskaplike besinning oor spiritualiteit na vore kom, maar tog ook die leemte dat 'n kernagtige definisie van spiritualiteit meermale ontbreek. Miskien sou spiritualiteit in 'n werksdefinisie vir hierdie artikel kernagtig omskryf kan word as ' $n$ lewe in geloof voor God en in diens van ons naaste vanuit die totale heilsopenbaring en heilstoe-eiening deur Gees en Woord in hierdie bedeling.

\section{Spiritualiteit in die lig van Romeine 12}

\subsection{Waarom Romeine 12 ?}

Die eerste motivering vir die verkenning van Romeine 12 vloei voort uit die breè struktuur van Romeine. Dit word aanvaar dat ons in die brief aan die Romeine basies die struktuur van 'n hofsaak het (Coetzee, 1995:49-51; Venter, 1997:22), naamlik aanklag, uitspraak, vonnis. Die vonnis kom in die vorm van 'n vryspraak. Na die vryspraak op grond van God se toegerekende geregtigheid volg Romeine 12 dan met as oorheersende motief die dankbare lewenswandel van die vrygespreekte gelowige. Dit is juis die vrygespreekte gelowige wat - op grond van die vryspraak - as lewende dankoffer coram Deo moet leef. Dit kan dus gesê word dat die breër struktuur van die Romeinebrief logies opbou tot en ook riglyne gee vir die spiritualiteit van die gelowiges. Juis daarom behoort Romeine 12 in meer besonderhede ondersoek te word.

Nie net uit die breër struktuur van die Romeinebrief nie, maar ook die nadere inhoud en struktuur van Romeine 12 bring ons by begrippe wat reeds hierbo in die aanduiding van bepaalde elemente in die raamwerk van spiritualiteit uitgelig is. Temas soos genade (ontferming 12:1), toewyding aan God (lewende dankoffer), eskatologie (huidige bedeling 12:2), volharding in liefde en dade van meelewing (12:9-21) kom na vore en hou verband met spiritualiteit.

\subsection{Die grond van spiritualiteit in Romeine 12}

Hierbo is reeds gestel dat spiritualiteit God se genade of bewerking van heil impliseer. In hierdie verband is dit insiggewend om te let op die voorkoms en betekenis van die begrip oiktirmos juis aan die begin van Romeine 12 waar begin word met die uitvoerige bekendstelling van die konsekwensies van die nuwe lewe 
in Christus. Die uitdrukking oiktirmos het in Romeine 12:1 die nuanse van "to show mercy and concern with the implication of sensitivity and compassion" (Louw \& Nida, 1989, I:751; vgl. Rienecker, 1980:11-29). Dié uitdrukking behels die betoning van die grootste genade aan iemand wat dit die minste verdien. Hierin lê dus die gedagte van 'n koning wat neerbuig na die mindere. As sodanig toon die begrip oiktirmos ooreenkoms met die Ou-Testamentiese begrip chesed. Hierdie begrip word in die Ou Testament in noue verband gebruik met God se verbond met sy volk, God wat in verhouding tree met sy volk en in hulle midde teenwoordig is. Snyman (1997:4) wys daarop dat die lyn dat God die teenwoordige God is, soos 'n goue draad deur sowel die Ou as die Nuwe Testament loop. God se teenwoordigheid by sy volk word sigbaar in die wolkkolom en vuurkolom. Later word God se teenwoordigheid vergestalt in die tempel. Die lyn van God se teenwoordigheid word in die Nuwe Testament voortgesit in die Immanuelformule in Matteus 2 en herhaal in die ek is met julle-uitspraak van Jesus in Matteus 28:20. As Jesus in die Evangelie van Johannes telkens die $E k$ $i s$-uitsprake gebruik, gryp Hy terug na God se verbondsuitspraak, "Ek is", in Eksodus 3 (vgl. Snyman, 1997:4).

In hierdie verband is dit insiggewend om daarop te let dat oiktirmos in Romeine 11 en 12:1 omruilbaar gebruik word met eleos. Eleos het die nuanse van "to show kindness or concern for someone in serious need" (Louw \& Nida, 1989, I:751) en is hier inhoudelik dus die ekwivalent van oiktirmos. Albei hierdie begrippe kom in die Romeinebrief uitsluitlik in hoofstukke 9 tot 12 voor met die swaartepunt in hoofstuk 11. Juis in hierdie hoofstukke word gehandel oor die feit dat God teenwoordig was en is by sy volk Israel, dat dit nie Hý is wat ontrou is nie. Telkens word Israel se ongehoorsaamheid en God se betoning van genade teenoor mekaar gestel. Nou is dit juis die omvattend gerigte ontferming van God in Romeine 9 tot 11 wat uitloop op die lofsang op God se ontferminge in Romeine 11:33-36 en oorloop in Romeine 12:1 op God se ontferming as diepste grond vir ons spiritualiteit (en kerkwees - volgens Romeine 12:6-8) en dan deurloop na Romeine 15:9 in die lofsang dat ook die nasies God vir sy ontferming sal prys (vgl. Venter, 1997:23).

By nadere ondersoek blyk dit dus dat God se ontferming aan die begin en weer aan die einde van Romeine 12:1-15:3 voorkom. God se ontferming vorm dus die raam waarbinne die totale vermaning en bemoediging van Romeine 12 tot 15:13 gesien moet word. God se ontferming is sodoende die begin en voltooiing van ons lewe van spiritualiteit coram Deo.

\subsection{God se soewereiniteit en ons spiritualiteit in Romeine 12}

In die vorige onderafdeling is betoog dat God se ontferminge die grond is vir ons spiritualiteit en dat sy ontferming basies beteken betoning van ontferming deur 'n koning aan mense in 'n toestand van ellende. 
Hierdie paragraaf fokus daarop dat die ontferminge juis die ontferminge van God is. Die voorsetsel dia word hier met die tweede genitief tou theou gebruik juis om God as volstrekte en enigste oorsprong aan te dui. Dit is verhelderend om die uitdrukking ontferminge van God in Romeine 12:1 te vergelyk met die uitspraak in 2 Korintiërs 1:2(b) waar van God gesê word "... Hy is die Vader wat Hom ontferm...". Letterlik staan hier dat God die Vader van ontferming is. Die metafoor - vader - wat hier gebruik word, beklemtoon weereens dat God die absolute oorsprong is van alle ontferminge. Dit is voorts veelseggend dat die uitdrukking Vader van ontferming hier nóú verbind word aan "... God, die Vader van ons Here Jesus Christus ..." (2 Kor. 2:3a). God as Vader wat ontferming betoon, word voorafgegaan deur God die Vader van ons Here (Kurios) Jesus Christus, deur wie God Hom ontferm.

'n Dimensie wat saamhang met die grond van ons spiritualiteit is dus die soewereiniteit van God, die Bron van die ontferming.

Prakties hou wat hierbo gesê is vir ons belewing van spiritualiteit minstens dit in: dat spiritualiteit innig beleef mag en moet word - dit gaan immers oor ontferminge - maar dat ons spiritualiteit nie net op belewenis gebou mag word nie. Bokant ons spiritualiteit staan die soewereine God as oorsprong van sy eie ontferminge.

\subsection{Toewyding aan God en spiritualiteit in Romeine 12}

As die ontferming van God dan die grond is van ons spiritualiteit, hoe lyk die persoonlike praktiese lewe in spiritualiteit? 'n Kardinale dimensie van ons spiritualiteit coram Deo word verwoord in Romeine 12:1(b): "Gee julleself aan God as lewende en heilige offers wat vir hom aanneemlik is". Die uitdrukking gee julleself kan hier ook weergegee word met stel julleself ten dienste van God (vgl. Wilckens, 1982:3). Die gedagte is dus diè van volle oorgawe, om jouself voluit in diens van God te stel.

Wat moet tot beskikking van God gestel word? Julleself (letterlik julle liggame) Ons het hier te doen met die stylfiguur van deel vir die geheel. Liggaam (sarks) staan hier vir die mens in sy geheel wat hom/haar aan God moet toewy. Die toewyding as dimensie van spiritualiteit word hier in kultiese taal weergegee as offer. Hierdie offer moet heilig wees. Heilig het hier 'n dubbele nuanse, naaunlik afgesonder van (die wêreld van sonde) vir God. Hierdie offer moet voorts vir God aanneemlik wees (1953-vertaling: welgevallig). Dié vereiste hou in dat die offer kongruent moet wees met God se wil. 
Die opstapeling van drietalle in hierdie verse is opvallend: My lewe as dankoffer moet

- heilig,

- lewend en

- vir God aanneemlik wees.

Aan die einde van vers 2 word die wil van God ook in drie uitdrukkings beskryf as

- goed

- aanneemlik en

- volmaak.

Die gerigtheid van die offer op die wil van God is hier opvallend.

'n Fyn trek kom ook na vore in die vereiste dat die offer van spiritualiteit lewend moet wees. In die Ou Testament is uitwendige offers gebring. Die offer van spiritualiteit wat gebring moet word, is nie meer uitwendig nie, dit is lewend. In die Ou Testament was dit praktyk dat die soenoffer voldoening bewerk het voor God. Na die soenoffer moes die Israeliet 'n dankoffer bring. Die dankoffer was primêr ' $n$ offermaal waar die deel van die offervleis wat nie tydens die soenoffer verbrand is nie, nou met lewende elemente (vrugte) geoffer word as 'n belydenis - saam met die huisgenote van die geloof - dat God my skuld vergewe het, dat ek nou in vryheid voor Hom en in vreugde met my naaste mag lewe (vgl. Coetzee, 1996:4; Bruce, 1985:212-213).

Tot dusver kan ons dus sê dat spiritualiteit die dimensies inhou van toewyding (as ten dienste stel aan God), van toewyding as offer en van toewyding as vreugde.

Uit vers 2 kom egter nog verdere nuanses in die toewyding aan die Here na vore. Hierdie nuanses kom na vore in 'n negatiewe en 'n positiewe bevel. Die negatiewe bevel hou in dat ons nie gelykvormig moet word aan hierdie (sondige) wêreld nie, dat ons lewe as't ware nie mag saamval met die skema van hierdie bedeling (aeon) nie. Spiritualiteit hou verandering, as't ware die ondergaan van 'n metamorfose in. Wat hierdie verandering konkreet (positief) inhou, is niks anders nie as vernuwing (anakainosis) en dan spesifiek in ons denke. Soos wat 'n ou rekenaar nuut geprogrammeer word en dan nuwe funksies aktiveer, so is die vernuwing wat in ons denke, in ons spiritualiteit moet plaasvind. Coetzee (1996: 5) wys daarop dat hier nie neos nie maar kainos gebruik word. Kainos dui op 'n ou ding wat nuutgemaak word.

Ons het hier sekerlik met een van die diepste dimensies in ons spiritualiteit te doen - die aflê (nie gelykvormig word) van die ou sondige lewe en die aantrek, 
die nuutgemaak word deur die Heilige Gees. Juis in hierdie vernuwing lê ook 'n Pneumatiese dimensie.

\subsection{Eskatologie en spiritualiteit in Romeine 12}

In die voorafgaande onderdeel is betoog dat die opdrag om nie aan hierdie sondige wêreld gelykvormig te word nie maar dat ons denke vernuwe moet word, ons bring by ' $n$ dieptedimensie in ons spiritualiteit. Hierdie nie gelykvormig word en vernuwe word moet plaasvind ten opsigte van die huidige bedeling, of hierdie aeon. Met die behandeling van die uitdrukking aeon kom ons op die terrein van die dubbele dimensie van tyd in die Nuwe Testament. Die nuwe bedeling het reeds aangebreek, maar moet ook nog voltooi word, net soos wat die lente sy voltooiing vind in die volle somer. Met die woorde hierdie sondige wêreld (aeon) fokus Paulus veral op dit wat tans nog ontbreek (Venter, 1985:40). Hierdie is nog die bedeling van die onvoltooidheid, van sonde wat reeds in beginsel oorwin is, maar wat tog nog 'n sekere greep op die gelowige het. Hierdie bedeling het nog 'n eie styl van optrede en 'n eie aard van lewe. Juis daarom is die huidige bedeling nog die bedeling van sonde, maar ook die bedeling van vernuwing.

Toegespits op ons spiritualiteit hou bogenoemde in dat ons ons spiritualiteit beoefen in 'n wêreld wat nog gebroke is. Daarom sal in ons spiritualiteit meermale aspekte van verflouing, van swakheid, van verloor voorkom. Terselfdertyd breek die nuwe aeon ook deur in die innerlike vernuwing en oorwinning wat in hierdie bedeling plaasvind.

\subsection{Die kerk en spiritualiteit in die iig van Romeine 12}

Aan die begin van hierdie artikel is reeds gestel dat Velema in sy ontleding van spiritualiteit ook aan die kerk 'n plek toeken. Die kerk waar die heil wat God bewerk, bedien word, word deur die Heilige Gees en die Woord byeengebring.

Die vraag is nou of daar sprake is van die kerk in Romeine 12 en indien wel, op watter wyse word hier van die kerk gepraat?

Inderdaad is hier sprake van kerk in die gebruik van die metafoor van die liggaam. Die metafoor van liggaam vir die kerk wil veral tot uitdrukking bring die dimensie van "believers in Christ who are joined together as a group with the implication of each having a distinctive function within the group (Louw \& Nida, 1989, II:127).

Dit is opvallend waarin die kerk volgens Romeine 12 gefundeer word. Met bepaalde voegwoorde word die liggaam van Christus-uitdrukking in Romeine 12:4-8 telkens verbind aan die eerste groter gedagte-eenheid in verse 1 en 2 . Hierdie voegwoorde is kathaper en gar. Vers 1 bring juis weer die werklikheid van God se ontferming as fundering van die kerk na vore (vergelyk hier Paulus se 
aanspreekvorm in sy vermaning in vers 1 . Ek doen ' $n$ beroep op julle broers op grond van God se groot ontferming).

Nie net die saak van die kerk, of die fundering van die kerk nie, maar ook die aspek van die toerusting - by implikasie dus toerusting tot en in spiritualiteit kom na vore in Romeine 12:4-8. Die kerk funksioneer soos 'n liggaam en kan alleen só funksioneer as hy toegerus word. Op die uiteensetting van die kerk as een liggaam met baie lede, volg van vers 6 af: Ons het genadegawes (charismata). Die liggaam word - ook in sy spiritualiteit - opgebou deur genadegawes en deur die konkrete beoefening van genadegawes (Venter, 1988:16). Binne die konteks van Romeine 12:4-8 moet die klem nie primêr op die voorkoms van die genadegawes gelê word nie, maar op die beoefening van die genadegawes, die konkrete bediening daarvan in die opbou van mekaar (vgl. Käsemann, 1980:332342), ook in spiritualiteit.

Wat hier in Romeine 12:4-8 na vore kom, is dus dat sowel die kerk as die lewe in spiritualiteit gefundeer moet word in die ontferming van God. Wat voorts prakties van belang is, is dat die gawes in die kerk die lewe coram Deo opbou en dat die gelowiges as lede mekaar ook onderling opbou in hulle lewe coram Deo. Met hierdie bevinding kom spiritualiteit en die opbou in spiritualiteit sterk na vore. Hierdie opbou vind plaas deur Woordbediening, gebed en nadere toerusting maar in besonder deur die onderlinge herderlike bediening van gelowiges aan mekaar.

\subsection{Konkrete aksies van spiritualiteit in die lig van Romeine 12}

\subsubsection{Die drie sirkels van liefdesbetoon}

Die struktuur van Romeine 12:9-21 vertoon iets van 'n drievoudige beweging in wyer wordende sirkels. Die eerste aksie vind binne die gemeente plaas, die tweede aksie vind teenoor alle mense plaas en die derde aksie vind plaas teenoor vyande.

Wat veral opvallend is in die eerste sirkel, die binnekring van spiritualiteitsbeoefening, is die imperatiewe tot konkrete dade van opregte liefde. Die begrip philostorgoi in vers 10a dui veral warm, toegeneë liefde binne die verband van 'n gesin aan (Rienecker, 1980:30). Hierdie gedagte van warm gesinsliefde as liefde tussen gemeentelede word ook versterk deur die pleonastiese gebruik van philos in philadelphia en philostorgos.

In sowel verse $10 \mathrm{a}$ as $10 \mathrm{~b}$ is die herhalingspatroon van allelous opvallend. Ware spiritualiteit mag nie net beperk word tot die eie persoonlike verhouding met God nie: dit moet ook in dade van liefde na buite gerig word - as die eerste toepassingsveld van die vrug van persoonlike spiritualiteit. 
As vrug van egte spiritualiteit volg egter ook 'n verdere sirkel buite die gemeente, naamlik die betoning van vriendelikheid teenoor alle mense. Die hoogste vrug van spiritualiteit (en sekerlik die hoogste eis!) word verder verwoord in Romeine 12:20: "As jou vyand honger is, gee hom iets om te eet en as hy dors is gee hom iets om te drink". Die nuanse hier is: as jou vyand op die dieptepunt van sy swakheid is (honger en dors), hou hom of haar in die lewe. Ware spiritualiteit staan lynreg teenoor doodmaak, selfs van 'n vyand. In hierdie verband haal John (1998:100) 'n uitspraak van Augustinus aan "The most important obligation of a friend is that of fraternal correction and forgiveness".

'n Nuanse wat ook verband hou met die optrede teenoor vyande is die imperatief om vyande (vervolgers) te seën en nie te vervloek nie. In die Ou Testament is die begrip seën 'n pregnante uitdrukking. Waar geseën of vervloek word, kom 'n aksie tot stand, iets gebeur soos wanneer God net spreek en dit gebeur. lemand wat in ware spiritualiteit voor God leef, mag nie op God se regterstoel gaan sit en deur vervloeking 'n oordeel uitspreek nie. 'n Ware toets vir spiritualiteit is of liefde ook liefde vir 'n vervolger of 'n vyand word (vgl. Schelke, 1973:78).

\subsubsection{Hoop, verdrukking, gebed en spiritualiteit}

Hierdie dimensie kom veral in vers 12 na vore. Hoop in verdrukking en gebed kan as grondliggende elemente in ware spiritualiteit beskou word. Dit is opvallend dat geloof en hoop binne die Romeinebrief veral in hoofstukke 5-8 funksioneer. Dit is in hierdie hoofstukke waar gehandel word oor die nuwe lewe van hulle wat onskuldig verklaar is deur God. Juis in die nuwe bedeling is die lewenswyse dié van geloof en hoop en (nog) nie van sien nie. Om hierdie rede word die begrip hoop in vers 12c gevolg deur die opdrag tot gebed (Venter, 1988:20). Gebed is 'n wesenskenmerk van die nuwe volk van God, die volk wat voor God lewe in spiritualiteit.

\subsubsection{Geestesywer en spiritualiteit}

In 'n artikel soos hierdie kan al die aksies as vrug van spiritualiteit nie behandel word nie. Om hierdie rede word volstaan deur te wys op uitgesproke aksies as vrug van die werking van die Gees in ons lewe van spiritualiteit. Hierdie elemente word in Romeine 12:11 verwoord. Die begrip wat in vers 11 a vir ywer gebruik word, is dieselfde as wat Romeine 12:8 vir die gesindheid en werk van 'n voorganger in die gemeente gebruik. Voorgangers is gawes van die Heilige Gees aan die gemeente. Dit is ook die Heilige Gees wat mense vurig van gees maak. Die Heilige Gees word in die Nuwe Testament meermale met vuur in verband gebring (Handelinge 2:3 en 1 Tessalonisense 5:19). Die afleiding kan dus gemaak word dat ware geesdrif in egte spiritualiteit niks anders is nie as Geesdrif. Hierdie Geesdrif lei tot 'n opregte dien van die Here. 


\subsection{Samevattende stellings}

- Die grond van egte spiritualiteit is God se ontferming vir mense wat dit nooit verdien nie.

- In die betoning van sy ontferming in Christus is God, as Vader van alle ontferminge, volstrek soewerein.

- Ware spiritualiteit hou in totale oorgawe en toewyding aan God in vreugde.

- Spiritualiteit hou ook nuut geprogrammeerde denke in.

- Spiritualiteit word deur ons beoefen in die eskatologiese bedeling van reeds en nog nie, dit wil sê in 'n bedeling van vernuwing deur die Gees, maar terselfdertyd ook nog 'n bedeling van sonde en gebrokenheid.

- Spiritualiteit kom in besonder tot sy reg in 'n kerk waar ampsdraers én lidmate vir mekaar sorg en mekaar toerus.

- 'n Vrug van spiritualiteit is konkrete liefdesdade in wyerwordende sirkels, dit wil sê vanuit die gemeente tot alle mense en ook tot vyande.

- Geloof, hoop en liefde is wesenselemente in die beoefening en uitlewing van spiritualiteit.

- In egte spiritualiteit is geestesywer gelyk aan Geestesywer wat motiveer tot diens aan God.

\section{Bibliografie}

BRUCE, F.F. 1985. Romans. Leicester : Inter-Varsity.

COETZEE, J.C. 1995. Route map to the books of the New Testament. Part 1 . The letters of Paul. Orkney : EFJS.

COETZEE, J.C. 1996. Eksegese van Romeine 12. Potchefstroom : Fakulteit Teologie

DREYER, T.F.J 1998. In verhouding met God. Die Hervormer, 90(20):2-5.

GELUK, M.P. 1995. The place of preaching in the church. Trowel \& Sword, 41(5):16-18.

JOHN, M R. St. 1998. Augustine's self-watch; a model for pastoral leadership. Bibliotheca Sacra, 155(617):92-103.

JONKER, W.D. 1989. Die eie-aard van gereformeerde spiritualiteit. Nederduitse Gereformeerde Teologiese Tydskrif, 30(3):288-299.

KÄSEMANN, E. 1980. Commentary on Romans. Grand Rapids : Eerdmans.

KIM, H.K. 1997. Preacher and spirituality: a diaconiological study in the light of the Pastoral Epistles Potchefstroom : PU for CHE (Th.M dissertation.)

LARTEY, E.Y. 1997. In living color. An intercultural approach to pastoral care and counselling London: Cassel.

LOUW, D.J. 1997. 'n Diagnostiese model vir die assessering van spiritualiteit met die oog op geloofsontwikkeling in die pastorale bediening. Praktiese Teologie in Suid-Afrika, 12(2): 11-25. 
LOUW, J.P. \& Nida, E.A. 1989. Greek-English Lexicon of the New Testament based on semantic domains. Volume 1 en 2. Roggebaai : Bible Society of South-Africa

OOSTENBRINK, J.W. \& LOTTER, G.A. 1998. Kleingroepe ter fasilitering van spiritualiteit in die kerk. In die Skriflig, 32(1):1-18.

RIENECKER, F. 1980. A linguistic key to the Greek New Testament. Vol 2. Grand Rapids Zondervan.

SCHELKE, K.H. 1973. Der Christ in der Gemeinde. Eine Auslegung von Rom 12. Bibel und Kirche, (28):74-81

SNYMAN, S.D. 1997. Spiritualiteit - 'n perspektief uit die Ou Testament. In die Skriflig, 31(4): $1-13$

VAN'T SPIJKER, W. 1998. Spiritualiteit by Augustinus De Wekker, 107(25):381

VELEMA, W.H. 1990. Nieuw zicht op gereformeerde spiritualiteit. Kampen : Kok Voorhoeve.

VELEMA, W.H. 1992. Geloof en gevoel. Leiden : Groen

VENTER, C.J.H. 1985. Die Pauliniese paranese in Romeine 12:1-15:143. 'n Eksegetiese studie. Potchefstroom : PU vir CHO. (Proefskrif - Th.D)

VENTER, C.J.H. 1988 'n Nuwe-Testamentiese profiel van 'n gemeente wat homself opbou (In Venter, C.J.H. red. God bou op deur sy Woord. Potchefstroom : Departement Sentrale Publikasies, PU vir CHO. p. 10-27.)

VENTER, C.J.H. 1997. Prediking oor politieke sake - riglyne vanuit Romeine 12-15. In die Skriflig, 31(1 \& 2):19-32.

WILCKENS, U. 1982. Der Brief an der Romer. 3 Teilband. Rom. 12-16. Neukirchener Benziger.

WITVLIET, J.D. 1997. The spirituality of the psalter. Metrical psalms in liturgy and life in Calvin's Geneva. Calvin Theological Journal, 32(2):273-297. 